\title{
Kultura i sjećanje na rat: Vukovarska bitka i njezini društveni odjeci
}

DOI: $10.11567 /$ met.32.2.4

UDK: 355.01(497.544Vukovar):316.7

355.1-058.65(497.544Vukovar):791.62

Prethodno priopćenje

Primljeno: 11. 12. 2015.

Prihvaćeno: 07. 10. 2016.

Mateo Žanić

Institut društvenih znanosti Ivo Pilar, Područni centar Vukovar, Vukovar mateo.zanic@pilar.hr

Krešimir Kufrin

Odsjek za sociologiju, Filozofski fakultet, Sveučilište u Zagrebu, Zagreb

\section{Dražen Živić}

Institut društvenih znanosti Ivo Pilar, Područni centar Vukovar, Vukovar drazen.zivic@pilar.hr

\begin{abstract}
SAŽETAK
Iz pozicije koja razmatra dinamičan karakter sjećanja u modernosti analiziraju se načini na koje se u Hrvatskoj oblikovala kultura sjećanja na Vukovarsku bitku te koje su se ključne rasprave oko toga vodile. Interpretiranje promjena koje su se događale u produkciji i recepciji sadržaja kulture sjećanja temelji se na dostupnim znanstvenim radovima, pisanju tiska, tumačenju ključnih sadržaja kulture sjećanja (knjiga, filmova i obilježavanja) te rezultatima empirijskog istraživanja provedenog putem intervjua. Smatra se da se pritom može govoriti o tri faze u kojima je kultura sjećanja bila različito aktualizirana. U prvoj fazi, koja se odnosi na godine progonstva (od 1991. do 1998.), dominira tema važnosti pamćenja bitke i prijeratnoga grada kako bi se po povratku prognanog stanovništva grad mogao obnoviti. Premda su se vodile polemike oko toga je li se grad mogao obraniti, je li se mogao prije vratiti pod suverenitet Republike Hrvatske te je li se moglo više učiniti za prognanu populaciju, Vukovar je tijekom devedesetih predstavljan kao ključno mjesto otpora agresiji koja se vodila protiv Hrvatske. U drugoj fazi, od 1998. do 2013., dominirala je ideja pamćenja kao temelja borbe protiv relativizacije istine. Ključno pitanje postaje na koji način kultura sjećanja može prenositi istinu o Vukovarskoj bici i kako se to treba odraziti na društveni poredak u gradu. U trećoj fazi, od 2013., kulturom sjećanja dominira rasprava o značenju Vukovarske bitke za nacionalni identitet i vođenje unutarnje politike. Zaključuje se da pomaci u tumačenju značenja sjećanja na Vukovarsku bitku upućuju na različite aspekte u kojima se očituje važnost kulture sjećanja u suvremenom društvu.

KLJUČNE RIJEČI: Domovinski rat, Vukovarska bitka, kultura sjećanja, nacionalni identitet, obilježavanje
\end{abstract}




\section{UVOD:KULTURA I SJEĆANJE NA RAT}

Prema riječima J. Lotmana i B. Uspenskog, kultura se može definirati kao pamćenje društva koje se ne prenosi genetski (Assmann, 2008). Sukladno tome kultura prožima društvene odnose i omogućuje društvene kontinuitete. No isto tako u kulturi svoje mjesto nalaze i povijesni lomovi, ratovi i revolucije o kojima se još desetljećima piše, polemizira i koji se nastoje reprezentirati kroz kulturu. Oko pitanja na koje se načine i putem kojih sadržaja prenosi sjećanje na prošle događaje konstituiralo se interdisciplinarno polje istraživanja nazvano studije pamćenja (Erll, 2011; Olick, Vinitzky-Seroussi i Levy, 2011).

S obzirom na to da je društvena teorija nastala kao rezultat razdoblja modernosti i kao izraz nastojanja da se objasne društvene transformacije koje je donijelo to razdoblje, ne čudi da je i pitanje pamćenja u modernosti izazvalo dosta pozornosti. U ovom radu modernost se tumači kao povijesno razdoblje koje počinje u 18. stoljeću i koje je uzrokovano političkim, kulturnim i ekonomskim promjenama koje se iz Europe šire svijetom izazivajući različite reakcije (Eisenstadt, 2004). Te promjene odnose se prije svega na procese racionalizacije države, širenja tržišta i dugotrajne tehnološke revolucije te se manifestiraju u ubrzavanju društvenih promjena, o čemu se obično govori kao o ubrzavanju vremena (Berger i Kellner, 1991).

Sva navedena obilježja modernosti našla su odjeka i u načinu prenošenja sjećanja na prošlost. Smatramo stoga da je opravdano govoriti o dinamičkom karakteru sjećanja u modernosti, koje se uspostavlja kako zbog umnožavanja načina na koje se prenosi kultura sjećanja tako i zbog promjena u društvenim okvirima u kojima pojedinci pamte (Berger, 1963; Hutton, 1993). Pretpostavlja se da je pamćenje i dalje važno za pripadnike društva, ali da se njegova važnost i vrijednosti ubrzano mijenjaju s promjenom društvenih odnosa. Stoga sadržaji sjećanja bivaju višeslojni i preklapajući, ali i dalje u kriznim razdobljima postoje težnje da se važni događaji jednoznačno kodiraju (Misztal, 2004). U tom kontekstu potrebno je istražiti razloge i oblike resemantizacija sjećanja u modernosti. Naime zbog ubrzavanja promjena pripadnici grupa $\mathrm{u}$ interakciji među sobom kao i u interakciji s pripadnicima drugih grupa stvaraju i interpretiraju sadržaje kulture sjećanja. Kroz te sadržaje selektiraju se epizode prošlosti koje treba pamtiti te načini na koje ih treba pamtiti. Pojedini akteri u tim prikazima bivaju prikazani kao žrtve, počinitelji zločina, heroji, izdajnici. No zbog dinamike unutargrupnih i međugrupnih interakcija prošlost nije nužno povlašteno mjesto kompromisa, već postaje i polje prijepora, polemika, pa i onoga što se naziva mne- 
moničkim bitkama (Zerubavel, 2007). Može se stoga praviti razlika između kulture pamćenja koja se fokusira ponajprije na pamćenje i pitanje kako unaprijediti sposobnost pamćenja, kako zapamtiti više i preciznije (Yates, 2011), te kulture sjećanja koja se bavi društvenom selekcijom i vrednovanjem prošlih događaja, njihovim identitetskim potencijalom. Tako koncipirana kultura sjećanja dobiva smisao u društvenoj kontekstualizaciji, odnosno pretpostavlja da grupe u susretu $\mathrm{s}$ društvenim promjenama prošlosti pridaju smisao i značenje (Berger i Luckman, 1992). Budući da se pojedinci kao članovi grupa tijekom života mogu kretati unutar ili između različitih društvenih svjetova, može dolaziti i do porasta ili slabljenja važnosti pojedinih sistema značenja za društvenu cjelinu ili pak stavljanja naglaska na specifične aspekte sistema značenja (Berger, 1963). Prošlost stoga, kao dio sistema značenja, može imati iznimno veliku identitetsku ulogu, ali se njezina važnost $u$ društvenim promjenama može mijenjati. Osim toga važno je uzeti u obzir da nemaju svi sadržaji kulture sjećanja isti odjek u javnosti. A. Assmann (2008) razlikuje stoga kanon i arhiv, one sadržaje koji imaju ključnu ulogu pri reprezentiranju prošlosti i one koji su u drugom planu. Stoga će se u ovom radu upotrebljavati termin »društvena aktualizacija« da bi se označio čin javnog isticanja pojedinih sadržaja koji se tiču prošlosti te njihova tumačenja i vrednovanja. Na različite oblike simbolizacije i aktualizacije prošlih događaja i važnost sjećanja za nacionalni identitet upućivao je u svojim radovima A. D. Smith $(1998,1999)$. Pokazao je pritom da proces društvene simbolizacije prošlosti može uključivati različite elemente kao što su heroji, žrtve ili zlatno doba. Smatramo međutim da je te elemente potrebno analizirati ne samo kao distinktivna obilježja nacionalnog identiteta već i u dinamici unutar grupne recepcije, koja uključuje i rasprave oko njihova pravog značenja.

Polazeći od naznačenoga povijesnoga konteksta modernosti i interpretativnog pristupa kakav se zagovara unutar kulturne sociologije, u ovom radu rekonstruiraju se faze vukovarske kulture sjećanja, pri čemu se upotrebljavaju sljedeći izvori ${ }^{1}$ :

- dostupna znanstvena literatura koju smatramo relevantnom za razumijevanje kulture sjećanja na Vukovarsku bitku

- najtiražnije hrvatske dnevne novine: Večernji list, Slobodna Dalmacija i Jutarnji list, te lokalne, dvotjedne Vukovarske novine. Tekstovi relevantni za kulturu sjećanja prate se od 1992. do 2015., osim u slučaju Jutarnjeg lista, od 1998. do 2015.

Misli se na pristup kakav predlažu Alexander i Smith (2005) te Reed i Alexander (2008). 
- najznačajniji sadržaji vukovarske kulture sjećanja, s posebnim fokusom na knjige svjedočanstava i filmove te obilježavanje 18. studenoga

- rezultati istraživanja provedenog putem intervjua od 10. rujna do 12. studenog 2014. U tom istraživanju provedena su 22 polustrukturirana intervjua koja su trajala između 14 i 66 minuta. Uvjet za sudjelovanje $\mathrm{u}$ istraživanju bio je da je ispitanik osobno sudjelovao $\mathrm{u}$ barem jednom obilježavanju Dana sjećanja na žrtvu Vukovara 1991.

$\mathrm{Na}$ temelju razmatranja društvene konstrukcije i recepcije sadržaja kulture sjećanja smatramo da je moguće razlikovati tri faze u kojima se sjećanje na bitku na različite načine društveno aktualiziralo. ${ }^{3}$

U prvoj fazi, od 1991. do 1998., dominirali su isticanje borbe pamćenja protiv zaborava, pamćenje grada kakav je bio prije progonstva i prisjećanje ratnih stradanja. U tom razdoblju isticala se nužnost povratka prognanog stanovništva u grad i vraćanja gradu europskog duha kakav ga je odlikovao prije rata.

Drugo razdoblje, između 1998. i 2013., smatra se razdobljem borbe protiv relativizacije istine. Javne rasprave dominantno su se vodile oko pitanja važnosti utvrđivanja istine o Vukovarskoj bici i Domovinskom ratu, razlikovanja žrtve i agresora te traženja pravde za žrtvu.

Trećim razdobljem, od 2013., dominiraju napetosti u vezi s rutinizacijom sjećanja. Rutinizacija se odnosi na proces u kojem dominiraju polemike oko toga treba li jedan povijesni događaj činjenično rekonstruirati i prepustiti institucionalnom posredovanju ili se događaju treba pridati šira simbolična vrijednost, važna za oblikovanje ili održavanje predodžbe kolektiva o sebi. Za jedne je pritom važna demitologizacija i deemocionalizacija povijesnih događaja, dok drugi smatraju da su upravo povijesni događaji ti koji čine distinktivni karakter grupe te onda kad im se prilazi kroz prizmu žrtve nije moguće izbjeći emocionalnu uključenost. Pitanje na koje su stizali različiti odgovori bilo je kolika je važnost Vukovarske bitke u usporedbi s neki drugim društvenim zahtjevima, kao što je onaj promicanja prava nacionalnih manjina.

Procesi i promjene koji su se događali u kulturi sjećanja pokazat će se važnim za interpretiranje učinaka značenja na oblikovanje identiteta pojedinih grupa u gradu kao i za promicanje novog identiteta grada te stoga i za razmatranje društvenih procesa koji su se događali u gradu nakon $\mathrm{Vu}$ kovarske bitke.

Više o istraživanju i rezultatima istraživanja vidjeti u Kufrin i Žanić (2016).

3 Radovi koji paralelno razmatraju i hrvatsko i srpsko oblikovanje kulture sjećanja na Vukovarsku bitku jesu Kardov (2006) i Žanić (2008). 


\section{VUKOVARSKA BITKA I NJEZINE POSLJEDICE}

Vukovar i njegovi stanovnici bili su prije dvadesetak godina suočeni s ljudskim stradanjima, demografskim gubicima i materijalnim razaranjima koji se ne pamte u njegovoj dugoj prošlosti bogatoj različitim događajima. Ratna kataklizma, koja je Vukovaru donijela tisuće mrtvih, ranjenih, nasilno odvedenih, zatočenih, nestalih, prognanih i izbjeglih osoba, kao i veliku izravnu materijalnu ratnu štetu procijenjenu na desetak milijardi kuna, gotovo je u cijelosti izbrisala povijesnu, kulturnu i sakralnu baštinu toga grada, sačuvanu često tek u fragmentima sjećanja. Višegodišnja okupacija i nebriga vlasti koje su tada upravljale gradom samo su pojačale intenzitet strahota s kojima su se 1997. počeli suočavati prvi vukovarski povratnici.

Na temelju objavljene znanstvene i memoarske literature, vrijednih povijesnih i arhivskih izvora te empirijskih istraživanja moguće je dobiti prilično sveobuhvatan, iako ne do kraja zaokružen, uvid u složene geopolitičke, vojne, društvene, žrtvoslovne, pravne, međunarodne i druge uzroke i obilježja Vukovarske bitke, u kontekstu procesa stvaranja i obrane hrvatske države.

$\mathrm{Na}$ tragu prethodnoga smatra se da Vukovarska bitka ima važno, a u nekim vidovima i prijelomno mjesto u povijesti današnje hrvatske države, osobito $\mathrm{u}$ procesu formiranja modernoga hrvatskog nacionalnog i kulturnog identiteta (Jurčević, 2000; Rogić, 1993; Rogić Nehajev, 1998). Dugotrajan otpor vukovarskih branitelja, u uvjetima izrazite neravnomjernosti u broju angažiranih vojnika te u količini i kvaliteti naoružanja i druge vojne opreme, između snaga hrvatske obrane s jedne i postrojbi Jugoslavenske narodne armije (JNA) i srpskih snaga (srpske teritorijalne obrane i paravojski) s druge strane, učinio je Vukovarsku bitku simbolom obrane i pobjede u Domovinskom ratu te ujedno i simbolom prkosa, hrabrosti, odanosti, domoljublja, zajedništva, požrtvovnosti...

Uvidom u rezultate dosadašnjih istraživanja kao i dostupnu dokumentaciju različite provenijencije razvidno je da su u napadima na Vukovar, a naročito neposredno po njegovoj okupaciji od pripadnika JNA i srpskih snaga, nad hrvatskim braniteljima i civilnim stanovništvom počinjeni brojni zločini pojedinačnih i masovnih likvidacija i etničkoga čišćenja nesrpskog stanovništva, namjernog uništavanja grada i onemogućivanja života njegovim stanovnicima uz nasilno mijenjanje demografskih struktura, namjernog i sustavnog uništavanja elemenata povijesne i kulturne baštine te zatiranja sjećanja. ${ }^{4}$

Iako nisu dokraja definirani pojmovi, za navedeno se u literaturi upotrebljavaju i termini urbicid, kulturocid i memoricid. U tom je smislu korisno upozoriti na radove Sjekavica (2012) te Stanić i Kutleša (2008). 
Premda zbog nepotpunih podataka još uvijek nisu u cijelosti istražene sve demografske, društvene i ekonomske posljedice agresije na Vukovar, ipak je moguće iznijeti njihov približan kvantitativni okvir te upozoriti na težinu i dalekosežnost negativnog utjecaja rata na različita područja poslijeratne obnove, povratka i razvoja Vukovara.

U kontekstu ovoga rada opravdanim se čini podsjetiti da je, prema podacima iznesenim 2006. pred Međunarodnim kaznenim sudom za ratne zločine počinjene na području bivše Jugoslavije, u postupku protiv »vukovarske trojke«- pukovnika JNA Mile Mrkšića, majora JNA Veselina Šljivančanina i kapetana JNA Miroslava Radića - u Vukovaru poginulo najmanje 1739 osoba. Riječ je o broju dobivenom usporedbom evidencija tadašnjeg Ministarstva zdravstva i socijalne skrbi i Uprave za zatočene i nestale Ministarstva obitelji, branitelja i međugeneracijske solidarnosti (Marijan, 2013). Tom broju svakako valja priključiti i još uvijek u cijelosti neutvrđeni broj poginulih pripadnika JNA (procjene se kreću od tisuću do nekoliko tisuća stradalih) i osobito srpskih paravojski te civila koji su živjeli i stradali na dijelovima Vukovara koji nisu bili pod kontrolom snaga hrvatske obrane (npr. Petrova Gora), a koji se na temelju dostupnoga arhivskoga gradiva Republike Srpske Krajine mogu procijeniti na najviše 350 osoba (Ružić i Živić, 2013).

Dakako, treba imati u vidu i podatak da se, prema podacima Uprave za zatočene i nestale Ministarstva branitelja, sa stanjem od 31. prosinca 2015., na popisu nasilno odvedenih, zatočenih i nestalih osoba nalaze još 303 osobe iz Grada Vukovara. Njihova sudbina do danas nije rasvijetljena, tj. nisu pronađene grobnice s njihovim posmrtnim ostacima ili one još uvijek nisu identificirane, a ekshumirane su iz neke od prije otkrivenih pojedinačnih i masovnih grobnica na užem ili širem području Vukovara. ${ }^{5}$

Najbrojnija skupina ratnih stradalnika bili su vukovarski prognanici. Premda se tijekom godina okupacije, iz različitih razloga, mijenjao službeno registrirani broj prognanika, on je na vrhuncu prognaničkog vala premašio 23.000 osoba ( $90 \%$ Hrvati), što je bila polovina prijeratnog stanovništva Vukovara (Živić, 2008). Završetkom procesa mirne reintegracije u siječnju 1998. počeo je brojniji povratak, ali se do danas, prema procjenama, u Vukovar vratilo manje od $60 \%$ u ratu registriranih prognanika, što upućuje na njihovu relativno uspješnu ekonomsku i socijalnu integraciju u sredinama privremenog smještaja, ali i na njihovu smrtnost u naseljima privremenog smještaja. To je, dakako, jedan od čimbenika sve nepovoljnijega poslijerat-

Evidencija nestalih osoba, Uprava za zatočene i nestale, Ministarstvo branitelja, Zagreb, prosinac 2015. 
nog demografskog stanja u gradu, a koje induciraju snažni depopulacijski procesi u demografskoj dinamici i razvoju demografskih struktura, naročito dobno-spolnog sastava stanovništva.

Uz ljudske gubitke Vukovar je pretrpio i osobito teške materijalne ratne posljedice na ekonomskoj, prometnoj i komunalnoj infrastrukturi, kao i na povijesnoj, sakralnoj i kulturnoj baštini, koja je posve razorena i otuđena. Posebno su teško stradale najvažnije urbane dominante Vukovara, ujedno simboli hrvatskoga identiteta grada (dvorac Eltz, franjevački samostan, barokna crkva Sv. Filipa i Jakova, Palača Srijem, Palača Kotarskog suda i dr.) (Karač, 2004). Prema Izvješću Državne komisije za popis i procjenu ratne štete iz 1999., za područje Grada Vukovara (naselja Vukovar, Sotin, Lipovača i Grabovo) procijenjena je ukupna izravna ratna šteta od 9,5 milijardi kuna, od kojih se 4,6 milijardi kuna odnosi na gospodarstvo, 2,3 milijarde na infrastrukturu te 2,6 milijardi na privatnu imovinu. $U$ vojnim djelovanjima uništene su 8272 obiteljske kuće i 552 višestambena objekta, s 5580 stanova, tako da su uništene ili teško oštećene ukupno 13.852 stambene jedinice, što je približno 90\% prijeratnoga stambenog fonda u Gradu Vukovaru (Živić, 2012).

Sva navedena stradanja utjecala su na to da i nakon Vukovarske bitke Vukovar ostane $u$ fokusu pozornosti hrvatske javnosti. Važno je stoga rekonstruirati kako su se u godinama nakon Vukovarske bitke prikazivale tragedija grada, žrtve stanovnika i važnost događaja za šire, nacionalno društvo.

\section{KULTURA SJEĆANJA I PRIKAZIVANJE VUKOVARA IZVAN VUKOVARA (1991. - 1998.)}

U prvim godinama nakon Vukovarske bitke kultura sjećanja bila je obilježena činjenicom da se Vukovar zamišljao i kulturno oblikovao u progonstvu, izvan Vukovara. U tom razdoblju osobito brojni i značajni sadržaji nastat će kroz narativizaciju sjećanja, premda su važna i obilježavanja različitih godišnjica te brojne izložbe koje su se o gradu organizirale u Hrvatskoj i svijetu, a pozornost se treba posvetiti čak i izgradnji nekih spomenika.

Kada je posrijedi pisanje o Vukovaru, ono je značajno kako u nizu književnih ostvarenja tako i u osobnim svjedočenjima sudionika vukovarskih događaja. Od 1992. i knjige J. Njavre Glava dolje, ruke na leđa objavljen je niz važnih djela u kojima se svjedoči o težini stradanja kojima su bili izloženi Vukovarci. Važnost pak Vukovara u hrvatskoj književnosti najbolje potvrđuju riječi D. Oraić Tolić: »Vukovar je emocionalni apsolut hrvatske kulture 
1990-ih bez konkurencije u povijesti žrtve i slave, zla i nade, očaja i pravde, poraza i pobjede, nacionalne povijesti i individualnih ljudskih sudbina « (Oraić Tolić, 2009: 581). Od pisaca o kojima autorica piše mogu se izdvojiti djela S. Glavaševića i P. Pavličića kao ona koja su imala najviše odjeka u hrvatskoj javnosti. S. Glavašević (1992) ostavio je za sobom sliku »mitskoga grada «, i to kako svojim ratnim izvješćima tako i posmrtno objavljenim Pričama o Vukovaru.

P. Pavličić objavio je tijekom devedesetih niz članka te važne knjige Šapudl, Dunav i Vodič po Vukovaru. U jednom tekstu pisanom 1991. napisao je: »Ja se ne bojim da će moj rodni grad izgubiti identitet. Mnogi su iz njega već otišli, golem broj njih i protiv svoje volje. Ali to ne znači da će se Vukovar promijeniti, to ne znači da će netko tko to želi od njega moći napraviti nešto drugo. Jer, svi koji iz Vukovara odu, prije se ili poslije onamo vraćaju, čak i onda kad im se to brani. Svima je u Vukovaru ostalo nešto bez čega nikako ne mogu živjeti« (Pavličić, 1992: 192). Naznačeno je već tada ono što će se ponavljati godinama poslije: da bi se spasio identitet Vukovara, on se mora obnoviti kakav je bio, ali iznad svega u grad se moraju vratiti oni koji su iz njega prognani. Isticanje stanovnika kao bitne sastavnice identiteta grada ono je što povezuje Glavaševića i Pavličića. Pišući o gradu u razdoblju pred pad grada, Glavašević je tu misao izrazio na jednostavan i nenadmašan način često citiranom rečenicom »Grad - to ste vi.« Rečenica je to koja se ne bez razloga zazivala u progonstvu; smatralo se da je grad bez prognanih stanovnika postao ne-mjesto, nešto čemu nedostaje odrednica preko koje bi se identificirao.

Čuvanje slike grada bila je težnja i brojnih izložbi posvećenih gradu. U prvim godinama progonstva aktivnu ulogu u organizaciji izložbi igrala je udruga Zeleni pokret Vukovar, koja je osmislila izložbu Vukovar se predstavlja Hrvatskoj i Europi. Izložba je uključivala fotografije, akvarele, plakate i arheološke izloške iz Vučedola. Kako bi se dočarala sva težina razaranja grada, izložba fotografija prikazivala je Vukovar prije rata, za vrijeme rata i nakon rata. Predstavnica udruge u to je vrijeme pisala: »Vukovar se ne smije zaboraviti, jer kad zaboravimo ono što je bilo tamo, zaboravljamo sami sebe« (Vukovarske novine, 24. srpnja, 1992: 5). Važna manifestacija organizirana je i u povodu obilježavanja 18. studenoga 1992., kada je u Meštrovićevu paviljonu u Zagrebu skupina od tridesetak slikara započela simboličnu obnovu Vukovara. Na temelju starih razglednica i slika te po sjećanju prognanih umjetnici su slikali pojedine istaknute vukovarske objekte. Ideja vodilja bila je da nakon povratka vlasnici kuća i institucije koje su u objektima smještene dobiju te radove, pa je akvarel I. Rabuzina bio namijenjen 
Vukovarskoj bolnici, a franjevačkom samostanu djelo I. Lackovića Croate (D. De., 1992).

Važnu ulogu u prikupljanju umjetničkog materijala i pripremi obnove grada igrao je i Gradski muzej Vukovara u progonstvu. Ta je institucija zajedno s klubovima Vukovaraca i Katoličkom crkvom bila važna i u organizaciji različitih obilježavanja, osobito onoga 18. studenoga, o kojem se u godinama progonstva najviše pisalo kao o danu vukovarske tragedije. Program obilježavanja tog dana uključivao je promocije knjiga, posjet grobljima, okupljanja u klubovima Vukovaraca i služenje misa posvećenih žrtvama (Kufrin i Žanić, 2016).

Obilježavanja su se od 1993. organizirala i kod spomenika koji će se nazivati Zid bola ili Zid plača i koji je po nekima predstavljao najznačajniji spomenik posvećen Domovinskom ratu uopće (Križić Roban, 2010). Spomenik je imao jednostavnu strukturu te se sastojao od cigli u dvije boje, od kojih su crne bile postavljene za ubijene osobe, a crvene za nestale i zatočene. Zid je napravljen kao simbolični znak nezadovoljstva radom UNPROFORa, ispred čijeg središta je postavljen, ali je tijekom godina postao mjesto okupljanja prilikom gotovo svih važnijih datuma obilježavanja stradanja iz Domovinskog rata. Taj spomenik urezao se u sjećanje mnogih koji su ga u različitim prigodama, osobito za važnijih obilježavanja, posjećivali. Tako je u rujnu 2014. u jednom intervjuu jedan ispitanik prisjećajući se važnih događaja iz razdoblja progonstva rekao:

Pa svakako ima više tih stvari, recimo ono što mi je bilo baš mučno, imali smo misu kod Zida boli, onaj što je bio na Črnomercu. To je bilo malo ono, tad su nam imena bila pred očima. Ti ljudi koji su u tim ciglama na neki način vidjeli, to me je ovako impresioniralo, nekako posebno me je dirnulo. Tada sam vidio da smo jadni, a promet dalje teče, život ide, drugima ljudima život ide, promet ide, a mi smo tu. (I 3$)^{6}$

Kako je već naznačeno, Vukovarska bitka ostavila je za sobom teške posljedice za Hrvatsku. Dovela je do gubitka teritorija i progona velikog broja stanovnika u situaciji kada je već postojao problem organizacije smještaja prognanika. Iz toga je proizašao niz prijepora, od kojih posebno treba izdvojiti tri: je li Hrvatska mogla više napraviti u obrani grada, je li se moglo postići više za prognane stanovnike i je li se moglo prije vratiti izgubljeni teritorij.

Tezu da Zagreb nije radio dovoljno za obranu grada odnosno da je odustao od Vukovara, uglavnom su javno iznosili pojedini akteri koji su bili ak-

Intervju proveden u okviru istraživanja Obilježavanje i sjećanje 23. rujna 2014. 
tivni u obrani grada. ${ }^{7}$ Premda postoje pokušaji da se na znanstveni način rasvijetli to pitanje, čini se da cijela slika nije potpuno jasna. Znanstvenici koji su se njime bavili nisu pronašli vjerodostojni dokaz da je vlast u Zagrebu namjerno činila propuste $u$ obrani grada. No jedno istraživanje provedeno 2006. pokazalo je da čak $24 \%$ građana Hrvatske smatra da je Vukovar žrtvovani grad, a njih $63 \%$ da je bilo namjernih propusta u pružanju potpore obrani Vukovara (Skoko i Bagić, 2007). To su očito pitanja koja i dalje muče hrvatsku javnost.

Pitanje kvalitete smještaja prognanika također je bilo predmetom kritika. ${ }^{8}$ Osobito je teško bilo prognanicima smještenim u tzv. Gortanovim barakama u Dugom Selu, koji su se žalili na (ne)higijenske uvjete, prokišnjavanje objekata te nedobivanje humanitarne pomoći. Nakon više od četiri godine progonstva predstojnica Regionalnog ureda za prognanike izjavila je da »nije dobro što niti danas nemamo točno utvrđen donji minimum standarda za prognanike« (Vukovarske novine, 13. rujna 1995: 5).

Naposljetku, prognanicima se neprestano obećavao povratak kućama, a progonstvo je potrajalo više od šest godina. To je svakako utjecalo i na smanjivanje šansi da će se prognanici u većem broju vratiti u svoj grad.

Usprkos navedenim problemima Vukovar je od same Vukovarske bitke zadobio poseban status $\mathrm{u}$ hrvatskoj javnosti. Iznimna požrtvovnost $\mathrm{u}$ obrani grada i težina stradanja ljudi u danima nakon okupacije učinile su da sve drugo bude manje važno. Ključne institucije koje su bile uključene u oblikovanje kulture sjećanja, kao što su Gradski muzej Vukovar, klubovi Vukovaraca, Katolička crkva i Vukovarske novine, usprkos isticanju brojnih teškoća rata i poraća, u prvi plan stavile su pamćenje herojske obrane grada s dugom kulturnom tradicijom koju je agresor potpuno uništio. Vukovar je postao grad koji stoji u temelju državnosti, grad heroj.

\section{KULTURA SJEĆANJA KAO BORBA ZA ISTINU I PRAVDU (1998. - 2013.)}

Završetkom procesa mirne reintegracije 15. siječnja 1998., dolazi do masovnijeg povratka prognanog stanovništva u grad. U sljedećim godinama kulturom sjećanja prevladavali su težnja za jasnim razlikovanjem agresora

U tom kontekstu vidi intervjue vođene s B. Borkovićem (M. Marković, 1993.) i N. Tothom (S. Lukić, 1994.).

8 O teškoćama prognaničkog života, pa i nalaženja smještaja svjedoči knjiga Z. Šimunovića Vukovarski dnevnik (1995). Ona usto pokazuje i kako su neke aktivnosti koje se mogu podvesti pod kulturu sjećanja (npr. promocija knjiga o Vukovaru) imale pozitivan efekt na prognanike. 
i žrtava te imperativ za kažnjavanjem počinitelja zločina. Te teme dominirale su u hrvatskoj javnosti, a bile su važne i za odnos Hrvatske prema međunarodnim akterima te uspostavu zajedničkog života hrvatske i srpske zajednice u gradu. Hrvatskom javnošću dominirala je tema podijeljenoga grada, a Vukovaru će tijekom godina biti često pridodavane i oznake siromašnoga i skupoga grada. ${ }^{9}$ Razlike u tumačenju Vukovarske bitke našle su krajem devedesetih godina prošlog stoljeća svoj izraz i u nekim elementima kulture sjećanja. Tako su Hrvati obilježavali 18. studenoga kao dan posvećen žrtvama podnesenim u obrani grada, dok su Srbi isti dan obilježavali kao Dan prestanka sukoba. Valja pritom dodati da tih godina nisu zabilježeni nikakvi incidenti prilikom obilježavanja. No pokazalo se da su hrvatska i srpska kultura sjećanja tih godina krenule u različitim smjerovima. Dok je s hrvatske strane kultura sjećanja zadobivala povratkom u grad veliki zamah, sa srpske strane ona je nestajala iz javnog života. Osim toga već obilježavanje 1998. godine pokazat će da Hrvati i Srbi neće lako naći zajednički jezik u vezi s tumačenjem onoga što se u Vukovaru događalo 1991. Ususret obilježavanju Samostalna demokratska srpska stranka (SDSS) izdala je zajedno sa Zajedničkim vijećem općina, Udruženjem žrtava rata te Udruženjem nestalnih i nasilno odvedenih proglas kojim su tražili od svih sudionika obilježavanja 18. studenoga dostojanstveno ponašanje. Iznijeli su stav da pravo na tugu i bol pripada svima podjednako te da pijetet prema svim poginulima obavezuje da se napravi korak k međusobnom približavanju (HINA: Jutarnji list, 1998: 9). Na taj proglas reagirao je Savez hrvatskih vojnih invalida Domovinskog rata tvrdeći da se među autorima proglasa nalaze i akteri agresije na Hrvatsku te su u dokumentu vidjeli primjer izjednačivanja krivnje za rat i falsificiranje povijesti (HINA: Jutarnji list, 1998: 9).

Pitanje utvrđivanja istine i kažnjavanja zločinaca bilo je postavljeno kao glavni cilj rada Međunarodnoga kaznenog suda za ratne zločine počinjene na prostoru bivše Jugoslavije. No još početkom stoljeća rad Suda postao je predmetom brojnih propitivanja te niza negativnih kritika, kako s hrvatske tako i sa srpske strane (Allcock i sur., 2010). U Hrvatskoj su kritike na rad Suda stizale ponajprije zbog podizanja optužnica protiv hrvatskih generala A. Gotovine (2001.) i J. Bobetka (2003.) te nepodizanja optužnica protiv vodećih ljudi iz Jugoslavenske narodne armije. U Vukovaru je pak rad Suda došao u prvi plan nakon što su u rujnu 2007. izrečene prvostupanjske presude tzv. vukovarskoj trojci. Prema izrečenim presudama, V. Šljivančanin osuđen je na pet godina zatvora (nakon žalbenih postupaka presuda je bila

Ispitivanje različitih aspekata podijeljenoga grada dominiralo je i u znanstvenim radovima. U tom kontekstu pogledati tekstove Corkalo Biruški i Ajduković (2009), Kardov (2006) i Žanić (2008). 
povećana na sedamnaest, a potom smanjena na deset godina), M. Mrkšić na dvadeset godina zatvora (preminuo u portugalskom zatvoru u kolovozu 2015.), dok je M. Radić oslobođen optužbi. Kazna izrečena osobama odgovornima za zločin počinjen na Ovčari, koja je prema hrvatskoj javnosti bila neočekivano mala, umanjila je kredibilitet Haaškog suda i dovela do toga da kritike na račun rada Suda upućuju čak i njegovi dugogodišnji pobornici (Pavlaković, 2013).

Kao rezultat toga Dan sjećanja na žrtvu Vukovara 1991. godine, 2007. održan je pod sloganom »U Vukovar za istinu i pravdu«. Tadašnja gradonačelnica Vukovara izjavila je uoči obilježavanja: »Ove godine je posebno teško zbog sramotne haške presude 'vukovarskoj trojci' za zločin na Ovčari. Vukovar je izrazio svoje nezadovoljstvo, vjerujem da to nikoga nije ostavilo ravnodušnim i nadamo se da ćemo ipak dočekati pravdu « (Butigan, 2007: 43). U kasnijim godinama, osobito nakon puštanja majora Šljivančanima iz zatvora, u Vukovaru se često ponavljao stav da međunarodne institucije nisu uspjele sagledati cjelokupna događanja oko Vukovarske bitke, kazniti krivce i tako zadovoljiti pravdu. ${ }^{10}$

Pitanje uspostavljanja odnosa između agresora i žrtve bilo je u središtu pozornosti i hrvatske javnosti. U prvim godinama nakon povratka posebnu je pozornost zaokupila ideja izgradnje grada o kojem se u hrvatskoj javnosti uobičajilo govoriti kao o »gradu heroju«. Naime grad koji je zatečen bio je u lošem stanju te je zahtijevao znatna sredstva i aktivnost da se u njemu omogući kvalitetan život. To je shvaćeno kao dobra prilika da se kvalitetno obnove važni gradski simboli, pri čemu bi se manifestiralo hrvatsko zajedništvo. Inicirana je akcija obnove u kojoj su sudjelovale sve hrvatske županije na način da je svaka trebala financirati obnovu po jednoga važnog objekta u gradu. Bila je to prilika da Hrvatska pokaže jedinstvo u Vukovaru. Godine 1997. na taj su način bile osigurane donacije za 24 važne zgrade, a čekalo se da se osiguraju sredstva za još osamnaest gradskih projekata. No na koncu akcija nije bila posve uspješna. Do 2001. završeno je osam objekata, a pokazalo se da »su odabrane zgrade za mnoge darovatelje bile preveliko financijsko opterećenje i novci iz donacije nisu bili dovoljni za cjelokupnu obnovu, a i na mnogim su gradilištima troškovi obnove bili značajno povećavani« (Nadilo, 2001: 661). Tijekom godina posebno se pratila obnova zgrada koje su se označivale kao važne za nacionalni identitet i srednjoeuropski identitet grada: franjevački samostan, crkva Sv. Filipa i Jakova, Hrvatski dom, dvorac Eltz i zgrada Grand hotel/Radnički dom.

10 Major Šljivančanin pušten je iz zatvora 2011., a reakcije na tu vijest mogu se pročitati u Vukovarskim novinama od 15. srpnja 2011. 
Usporedo s obnovom važnih objekata došlo je i do oblikovanja mjesta sjećanja iz Domovinskog rata. Među izgrađenima spominjemo one najvažnije: spomen-obilježje na mjestu masovne grobnice na Ovčari i Spomendom Ovčara, spomenik na Memorijalnom groblju žrtava iz Domovinskog rata, »Mjesto sjećanja « - Spomen-muzej u podrumu Vukovarske bolnice, bista Blage Zadre i Spomen-dom branitelja na Trpinjskoj cesti.

Može se sumirati da je vukovarska kultura sjećanja bila vođena idejom da se naznače sva mjesta stradanja i ubijanja kako bi se odao pijetet žrtvi i spoznala istina o događanjima 1991. u Vukovaru. Sama obnova grada i izgradnja mjesta sjećanja bile su praćene govorom o potrebi prisjećanja žrtve i kažnjavanja počinitelja zločina. Zagrebački gradonačelnik M. Bandić govorio je prilikom otvaranja Spomen-doma na Ovčari o tome mjestu kao o hrvatskom Auschwitzu (Žanić, 2014b). No istovremeno u Hrvatskoj su jačale polemike oko toga kako predstavljati Domovinski rat i odnose različitih aktera koji su u njemu sudjelovali.

Jedan od onih koji je smatrao da je došlo do promjene odnosa prema Domovinskom ratu, pa i Vukovarskoj bici, bio je i S. Letica. On je, kao i neki drugi akteri, bio mišljenja da se u hrvatskome javnom prostoru odvija proces u kojem granice između agresora i žrtve kod opisa događaja iz rata bivaju sve nejasnije. ${ }^{11} \mathrm{U}$ listopadu 2003. ustvrdio je da Vukovarska bitka nije postala, kako se sam nadao, dio »korisne prošlosti« na kojoj se grade nacionalni ponos, nacionalno pamćenje, osjećaj zajedništva i na koncu budućnost. Umjesto toga, pisao je, »tematika Vukovara i cijeli Domovinski rat pojavljuju se u hrvatskoj i svjetskoj javnosti već nekoliko godina kao tragična i nepravedna crna kronika. Brojna samoubojstva branitelja te sjene javnih i tajnih optužnica Haaškog tribunala stvaraju u javnosti dojam kako je samo ratovanje za obranu i oslobađanje Hrvatske bilo zločinački, moralno dvojben ili, u najmanju ruku, suvišan, uzaludan posao. Negativni i demonski publicitet koji već nekoliko godina prati Domovinski rat i njegove ratnike ukida, na simboličkoj i predodžbenoj razini, ali, nažalost, i na političkoj i pravosudnoj razini, mnoge razlike između agresora i žrtve, između 'njih' (JNA i srpskih paravojnih postrojbi) i 'nas' (Hrvatske vojske, hrvatskih branitelja i osloboditelja)«(Letica, 2004: 8).

Koliko je osjetljivo pitanje prikazivanja Vukovarske bitke, njezinih junaka i žrtava, pokazalo je i premijerno prikazivanje prvoga hrvatskog igranog filma koji se eksplicitno bavio tom temom. Riječ je o filmu Zapamtite Vukovar F. Hadžića koji je prikazan na Hrvatskoj televiziji u studenome 2008. Film se

11 Misli se na izjave P. Pavličića i Z. Tomca izrečene u ovom razdoblju. O njihovim izjavama više u Žanić (2014a). 
bavi sudbinom grada nakon okupacije kroz priču o glavnom liku, djelatniku Hrvatskog radio Vukovara, koji uz pomoć vojnika JNA izbjegne strijeljanje na Ovčari. Zbog načina na koji su prikazani pojedini događaji, a posebno zbog prikazivanja »stvarnih likova«, djelatnika Hrvatskog radio Vukovara, slijedio je niz negativnih reakcija branitelja, koji su razmatrali i podizanje sudske tužbe protiv redatelja. S. Glavašević prikazan je primjerice kao lik koji se mijenja nakon okupacije na način da od energičnog novinara postaje šutljivi zarobljenik koji izbjegava dijalog s okupacijskom vojskom. Hadžić je uzvratio da je zadovoljan svojim filmom te ustvrdio da mu je drago što je napravio film Zapamtite Vukovar jer u njemu ništa nije krivotvoreno. Istovremeno je izrazio žaljenje što obitelji Glavašević i Polovina nisu zadovoljne filmom, ali je inzistirao na tome da je dobro upoznat s događajima u Vukovaru jer je punih osam mjeseci proučavao sva svjedočanstva i svu dostupnu građu (Dugandžija, 2008). Napokon, smatrao je da kao autor igranog filma ima pravo na određenu autorsku slobodu isto kao što ju je imala i A. Mirković pri pisanju svoje knjige o događajima u ratnom Vukovaru. Polemike oko ovog filma pokazale su koliko je teško napraviti film koji bi bio prihvaćen od javnosti i kritike $\mathrm{u}$ trenutku kada postoje društvene tenzije $\mathrm{u}$ vezi $\mathrm{s}$ relativizacijom istine i u kojem je $\mathrm{u}$ prvom planu inzistiranje na razlikovanju počinitelja i heroja/žrtava.

Znanstveni radovi također su se bavili analizom vukovarske žrtve i njezina statusa. S. Špoljar Vržina (2007) pisala je, analizirajući ponajprije vođenje međunarodne politike, o kontinuitetu marginaliziranja vukovarske žrtve. U tom kontekstu pisala je o posramljivanju žrtve do koje dovodi međunarodna politika pomirenja »balkanskih « zaraćenih strana koja ne vodi računa o stvarnim povijesnim događajima.

Napokon, u toj interakciji lokalnih, nacionalnih i međunarodnih aktera jedna presuda Međunarodnog suda za ratne zločine počinjene na prostoru bivše Jugoslavije dovela je do toga da se činilo da je odnos agresora i žrtve ipak utvrđen kada je posrijedi Domovinski rat i da će priča na tu temu gubiti važnost u javnosti. Naime 16. studenoga 2012. izrečene su drugostupanjske oslobađajuće presude hrvatskim generalima A. Gotovini i M. Markaču, čime je i oborena teza o udruženome zločinačkom pothvatu, što je bio adut onima koji su tvrdili da su u ratovima na tlu bivše Jugoslavije svi podjednako krivi. Dva dana nakon izricanja presude u Vukovaru je održano obilježavanje Dana sjećanja tijekom kojeg su brojni sudionici izjavljivali kako im obilježavanje te godine izgleda netipično te da se s tugom miješaju ponos, olakšanje, pa čak i zadovoljstvo (Žanić, 2014a). Govorilo se tada da je nakon pravog rata napokon okončan i pravni rat. Sam general Gotovina 
na povratku iz Haaga pred mnoštvom ljudi koji su ga dočekali u Zagrebu izjavio je da je vrijeme da se Hrvatska okrene budućnosti.

\section{VUKOVARSKA KULTURA SJEĆANJA ILI KOJE JE ZNAČENJE PAMĆENJA ZA NACIONALNI IDENTITET (OD 2013.)}

Povratak u Vukovar važan je društveni čimbenik koji je utjecao na promjene iz kojih se može rekonstruirati relativno jasna razlika između dvije faze vukovarske kulture sjećanja. Od 2013. pak u kulturi sjećanja opada važnost razlikovanja agresora i žrtve, a u prvi plan dolazi vrednovanje herojstva i žrtve u odnosu spram drugih nacionalnih vrijednosti i ciljeva. Ipak, kako dijelom počiva i na prijašnjim raspravama, ovu fazu nešto je teže jasno razdvojiti od prethodnih razdoblja. Treba naime spomenuti da je već rasprava o slabom poznavanju učenika srednjih škola gradiva koje se tiče $\mathrm{Vu}$ kovarske bitke dotaknula i teme vrednovanja tog događaja (Pavičić, 2010). Još se eksplicitnije tom temom, kroz prizmu demitologizacije Vukovara, bavio A. Bing u radu objavljenom 2013., ali izloženom godinu dana prije na znanstvenom skupu. Osim toga i prve rasprave o dvojezičnosti na gradskoj su se razini javile još 2010. U siječnju te godine zamjenik gradonačelnika iz redova SDSS-a D. Drakulić zatražio je dostavljanje materijala na srpskom jeziku i ćiriličnom pismu vijećnicima svoje stranke, pozivajući se na članak 61. Statuta grada Vukovara. ${ }^{12}$ Već se tada pokazalo da građani različito, pa i oprečno, reagiraju na to pitanje. Dok su neki smatrali da bi ćirilica obogatila kulturni prostor grada, drugi su smatrali da joj zbog događaja iz 1991. nikako nije mjesto u Vukovaru. ${ }^{13}$ Ipak, pitanje ćirilice tada je bilo lokalnoga gradskoga karaktera i tek nekoliko godina poslije spojit će se s uobličivanjem nacionalnog identiteta. Premda je dakle već dolazilo do tematiziranja Vukovarske bitke u kontekstu njezine vrijednosti za nacionalni identitet, to tek 2013. postaje dominantna tema koja obilježava kulturu sjećanja. Sada se, u osnovi, akteri ne slažu oko toga treba li Vukovar nakon bitke imati posebni status i kakav taj status treba biti ili, drugačije rečeno, treba li naciji mitsko mjesto, mjesto o kojem će se govoriti s pijetetom i koje će poticati snažne emocije.

12 Treći stavak, čl. 61 Statuta Grada Vukovara usvojenog 14. srpnja 2009. glasi: »U skladu s odredbama Ustavnoga zakona o pravima nacionalnih manjina i ovoga Statuta, pripadnici srpske nacionalne manjine imaju pravo slobodne uporabe srpskog jezika i ćiriličnog pisma u društvenom i javnom životu, te $u$ službenoj komunikaciji u javnim poslovima iz samoupravnog djelokruga Grada Vukovara« (Grad Vukovar, Službeni vjesnik, br. 4, Vukovar, 2009: 136).

13 Pogledati rubriku reakcije građana na pitanje »Podržavate li prijedlog SDSS-a o uporabi ćirilice u službenim institucijama?« objavljenu u Vukovarskim novinama 29. siječnja 2010., str. 4. 
Ta pitanja doći će u prvi plan nakon što su u prosincu 2012. objavljeni konačni rezultati popisa stanovništva provedenog 2011., a koji se odnose na narodnosni sastav stanovništva. Prema njima, u Gradu Vukovaru kao administrativnoj jedinici Vukovarsko-srijemske županije živi ukupno 27.683 stanovnika, od kojih je Hrvata 15.881 ili 57,4\%, a Srba 9654 ili 34,9\%, pa su Srbi prvi put premašili trećinu ukupnog stanovništva grada (Živić, 2013). Na prvoj sjednici Gradskog vijeća po objavi rezultata, predstavnici Samostalne demokratske srpske stranke (SDSS) zatražili su da im se sukladno Ustavnom zakonu o pravima nacionalnih manjina omogući ravnopravna uporaba srpskog jezika i ćiriličnog pisma. Reakcija dijela hrvatske javnosti i Hrvata iz Vukovara bila je burna. Upozoravalo se na simboličnu važnost grada i pojedinih lokacija u njemu te se izražavalo negodovanje stanjem $\mathrm{u}$ kojem bi Ovčara bila označena i ćiriličnim natpisom. U siječnju 2013. u Vukovaru su branitelji i stradalnici rata osnovali Stožer za obranu hrvatskog Vukovara, koji je iskazao protivljenje primjeni zakona u Vukovaru smatrajući da u njemu još nisu stvoreni uvjeti za uvođenje srpskog jezika i pisma. ${ }^{14}$

No predstavnici Vlade od početka su se odlučno zalagali za primjenu zakona, upozoravajući da nema prostora za njegovu izmjenu. Po objavi rezultata popisa stanovništva moglo se pročitati: »Ministar uprave Arsen Bauk u kratkom telefonskom razgovoru podsjetio je da je i premijer Zoran Milanović rekao da je riječ o jako dobrom zakonu te da će biti određen primjeren rok da se sve to napravi kako zakon propisuje. Napomenuo je i da nikakve peticije ne mogu zaustaviti provedbu zakona te da se njegove izmjene mogu napraviti samo u Saboru, ali da je za to potrebno osigurati 101 glas« (Bradarić, 2013: 12).

U veljači 2013. u gradu je održan prosvjedni skup na kojem se okupilo dvadesetak tisuća ljudi. Već su tada neke poruke sa skupa upućivale na to da su se temeljne napetosti prebacile s odnosa Hrvata i Srba na šire napeto-

14 Vjerojatno najvažnija aktivnost Stožera tijekom 2013. bila je inicijativa za raspisivanje referenduma o promjeni članka 12, stavka 1 Ustavnoga zakona o pravima nacionalnih manjina, u dijelu koji se odnosio na povećanje udjela nacionalne manjine, na temelju kojega je pojedina nacionalna manjina mogla ostvariti pravo na službenu uporabu svojega jezika i pisma (s trećine na polovinu ukupnog stanovništva u jedinici regionalne samouprave i lokalne uprave). Na zahtjev Hrvatskoga sabora da ocijeni je li referendumsko pitanje u skladu s Ustavom Republike Hrvatske Ustavni sud svojom Odlukom od 12. kolovoza 2014. nije dopustio raspisivanje referenduma (prema: Ustavni sud Republike Hrvatske, broj: U-VIIR-4640/2014, od 12. kolovoza 2014.). Ujedno, Ustavni sud istom je Odlukom odredio i korake koje je potrebno poduzeti da se riješi pitanje dvojezičnosti u Gradu Vukovaru. Jedan od koraka bio je i izglasavanje novoga gradskog Statuta, što je i učinjeno. Vlada Republike Hrvatske krajem 2015. poslala je i novodoneseni Statut Grada Vukovara na ocjenu ustavnosti. Do završetka rada na ovom tekstu nije bila poznata odluka Ustavnoga suda Republike Hrvatske. 
sti u hrvatskom društvu, što će posebno doći do izražaja u razdoblju nakon rujna iste godine u reakcijama na postavljanje dvojezičnih ploča.

Naime, usprkos povremenim reakcijama na pitanje dvojezičnosti, hrvatska se javnost nakon skupa održanog u travnju 2013. na Trgu bana Jelačića u Zagrebu pomalo odmaknula od tog problema. No sve se promijenilo kada su 2. rujna 2013. u ranim jutarnjim satima postavljene ploče s dvojezičnim natpisima na državne institucije u Vukovaru. To je dovelo do iznimno napete situacije u gradu, koji će se uspoređivati s Beirutom. Narednih mjeseci brojni građani predvođeni braniteljskim udrugama izlazili su na ulice i okupljali se oko objekata s postavljenim pločama te ih skidali, dok je s druge strane dovođeno sve više policije u grad te su postavljane ploče koje je bilo sve teže oštetiti. Hrvatski premijer i pojedini ministri iskazali su potrebu za dosljednošću u zaštiti manjinskih prava te istaknuli važnost provedbe zakona kojima se regulira pitanje dvojezičnosti. Ministrica vanjskih poslova iznijela je svoje viđenje problema: »Budućnost Vukovara kao hrvatskoga, ali i europskoga grada upravo je u njegovoj multikulturalnosti i višeetničnosti. Ako jedan grad u ovom trenutku treba tu svoju tradiciju, to je Vukovar« (nepotpisan prilog, Večernji list, 2013: 4). Pripadnici Stožera isticali su važnost stradanja i žrtve Vukovara te osjetljivost ljudi u gradu u kojemu mnogo toga poslije rata nije riješeno. Stoga je, prema mišljenju jednog njihova predstavnika, bilo važno ne samo iznova podsjetiti na važnost Vukovara za nastanak Hrvatske nego i zaštititi građane »koji su jako stradali u Domovinskom ratu i u ovom trenutku ne mogu učiniti taj demokratski iskorak ka potpunoj dvojezičnosti u gradu Vukovaru« (Butigan, 2013: 5).

Posebnu pozornost privuklo je skidanje dvojezičnih natpisa početkom listopada 2013., kada se ispostavilo da je ploču skinuo jedan od policajaca koji je bio zadužen za njezino čuvanje. Bila je riječ o dvadesetpetogodišnjem djelatniku Policijske postaje Ilok I. Gilji, kojem je otac kao branitelj stradao u Domovinskom ratu. Gilja je poslije pričao: »Dogodilo se u trenutku. Skinuo sam je na mah, bez ikakva razmišljanja o posljedicama koje bi mogle nastupiti. Nitko nije znao što ću učiniti, pa ni ja sam« (Rašović, 2013: 22).

Sve to odrazilo se i na događaj koji je tijekom godina postao najznačajniji sadržaj vukovarske kulture sjećanja, Dan sjećanja na žrtvu Vukovara.

Još na obilježavanju osnivanja 204. vukovarske brigade u rujnu 2013. predsjednik Stožera najavio je da bi na obilježavanju Dana sjećanja moglo biti neuobičajenih scena. Tada je izjavio: »Najavili smo kako ćemo za Dan sjećanja na žrtvu Vukovara biti negostoljubivi prema Vladinim dužnosnicima koji dođu, pa onda ne možemo sada s njima zajedno sjediti i praviti se da je sve u redu« (Vukovarske novine, 4. listopada 2013: 8). 
Kako su najavili, pripadnici Stožera iskazali su tijekom obilježavanja dvadesetdvogodišnjice okupacije grada svoje neslaganje s politikom Vlade, i to tako što su organizirali polazak kolone sjećanja prije nego što je to predviđao službeni protokol. Kolona kojoj se pridružila većina građana krenula je rutom kroz Županijsku ulicu i Ulicu Antuna Bauera te je tako blokirala put protokolarnoj koloni u kojoj je bio državni vrh, a potom je ispred njih postavljen niz lampiona. Političari koji su bili u koloni čekali su da prođe prva kolona, ali su potom odustali od puta prema Memorijalnom groblju. Samo obilježavanje i njegov učinak tumačili su se na različite načine, pri čemu su pripadnici Stožera bili ohrabreni time što je velika većina građana krenula u koloni koju su oni predvodili, dok je predsjedniku i ostalim političarima koji su napustili obilježavanje išlo na ruku medijsko izvještavanje, kojim je dominirala teza da se podjelama gubi važnost obilježavanja. Kolumnisti koji su implicitno ili eksplicitno podupirali pozicije Vlade pisali su tada o vukovarskim događajima kao o dijelu, prema njima sporne, konzervativne revolucije. Smatrali su da se hrvatsko društvo u susretu s krizom ponaša posve pogrešno te da krivce traži u nezaštićenim manjinama (Butković, 2013: 9; Pavičić, Slobodna Dalmacija, 2013: 14-15). Uzročnike problema tražili su u oporbenim strankama i Katoličkoj crkvi.

Nasuprot tome javljali su se glasovi da je Vlada sama kriva za to što joj se događa jer nije dobro procijenila situaciju i nepotrebno se upustila u projekt postavljanja dvojezičnih ploča u gradu u kojem postoje brojni ratni problemi i u kojem popis stanovništva i dalje nije pouzdan (Ljubičić, 2013: 6). Tvrdilo se i da pojedini akteri u hrvatskoj javnosti iskrivljavaju činjenice i nude pogrešna tumačenja događaja iz 1991. samo kako bi se predstavili kao "progresivni« $\mathrm{i} »$ multikulturni« (Nazor, 2014).

S obzirom na tenzije iz 2013. ne čudi što je već približavanje obilježavanja 2014. naišlo na iznimnu pozornost javnosti. Pod povećalom je bilo i obilježavanje dana 204. vukovarske brigade, kada je došlo do skidanja dvojezičnih ploča na javnim ustanovama. Premda su se pojavljivale teze da mediji nepotrebno preuveličavaju važnost podjela ili da je riječ o običnim političkim igrama, mnogi su se Vukovarci zbog novonastale situacije osjećali loše. To odražava i izjava jednog ispitanika u intervjuu vođenom u rujnu 2014., u kojem je on sjećajući se prethodnog obilježavanja rekao:

Meni je to bilo prilično frustrirajuće. Ne želim sada kriviti nekoga za nešto, ali jednostavno mi nije jasno zašto se cijelo vrijeme radilo na tome da se stvore uvjeti da se tako nešto dogodi. I uopće, sve ono što se događalo kroz mjesec, dva prije, prije samog obilježavanja je bilo barem za mene bilo izuzetno dramatično $i$ teško sam to proživljavao na osobnoj razini. Znači, sada u nekim godinama kada 
sam zreliji $i$ iskusniji, kažem, to je sada bilo i daleko potresnije za mene, nego li u onom trenutku kada sam čuo da je Vukovar pao. ${ }^{15}$

Samo obilježavanje Dana sjećanja 2014. na koncu je prošlo bez većih tenzija, čemu je pridonijelo i to što se u međuvremenu napravio određeni napor da se problem riješi pravnim putem. Osim toga sigurno je određenu ulogu u smanjenju tenzija oko obilježavanja imala i promjena vlasti na lokalnoj razini, pri čemu se novi gradonačelnik iz redova Hrvatske demokratske zajednice nedvojbeno izjašnjavao protiv primjene zakona o dvojezičnosti u gradu. Ipak, sam početak obilježavanja bio je »zbunjujući«. Nakon što je jedna manja kolona krenula znatno prije predviđenog vremena, isto je učinila i kolona u kojoj su bili predstavnici Stožera i u kojoj se isticala četrdesetak metara velika hrvatska zastava. Nakon što je krenula i protokolarna kolona, ključni trenutak dogodio se opet na križanju ulica A. Stepinca i A. Bauera. Naime 2014. nije došlo ni do kakve blokade te su se dvije kolone stopile u jednu. Na koncu je obilježavanje u javnosti ocijenjeno kao pobjeda dostojanstva i znak da je Hrvatska u Vukovaru bila jedinstvena.

U sjeni događaja oko uvođenja dvojezičnosti dogodilo se još nešto važno za vukovarsku kulturu sjećanja, osnivanje Javne ustanove »Memorijalni centar Domovinskog rata Vukovar « na sjednici Vlade 2. svibnja 2013. Kako se može saznati iz Statuta Ustanove, njezin je cilj promocija vrijednosti Domovinskog rata, prezentacija memorijalno-dokumentacijske građe, organizacija posjeta učenika i drugih posjetitelja Vukovaru te upravljanje ključnim mjestima sjećanja u gradu i njihovo održavanje. No, kako se čini, jedan od ključnih gradskih simbola, novi Vodotoranj, neće se naći među objektima pod nadležnosti Memorijalnog centra. Naime Gradsko vijeće donijelo je na sjednici u siječnju 2015. odluku da će Grad nastaviti upravljati s tim simbolom Domovinskog rata. Riječ je naime o objektu s čijim se planovima konzervacije/rekonstrukcije dosta lutalo, pa je to moglo utjecati na gradske vijećnike da ga zadrže pod gradskim nadzorom. Vukovarski gradonačelnik znakovito je izjavio: »Vodotoranj je postao najprepoznatljivijim simbolom Vukovara, nadrastao je Vučedolsku golubicu. Ne možemo dopustiti da Vodotoranj ode u prenamjenu, da tamo budu poslovni prostori... Ne možemo dopustiti da posljednji simbol rata ode u tom smjeru. Dopustimo li to, izgubiti ćemo posljednji trag rata te uništiti simbol« (Vukovarske novine, 6. veljače 2015: 4). Gradonačelnik je tako kritizirao Memorijalni centar da svojim planovima želi umanjiti simboličnu važnost Vodotornja, a odlučno je odbio i prijedlog ministra branitelja po kojem je ta ustanova trebala postati orga-

15 Intervju vođen 26. rujna 2014. u okviru istraživanja Obilježavanje i sjećanje. 
nizatorom obilježavanja Dana sjećanja na žrtvu Vukovara. Štoviše, upravo kroz obnovu Vodotornja nova gradska vlast pokrenula je projekt u kojem je Vukovar iznova promoviran kao simbol hrvatskog jedinstva i solidarnosti.

U svakom slučaju, događaji u vezi s vukovarskom kulturom sjećanja i dalje privlače veliku pozornost javnosti. No pokazalo se da dok se Vukovar i dalje prikazuje kao važan nacionalni simbol, simboli nemaju za sve ne samo isto značenje nego ni istu vrijednost. Za jedne simbolični oslonac nacionalnog identiteta treba biti smjer vodilja nacionalne politike, dok za druge prioritet trebaju imati Ustavom propisana prava nacionalnih manjina i politika multikulturalizma. Kako se god stvar dalje razvijala, Vukovar se našao u srži razmišljanja o hrvatskome suvremenom nacionalnom identitetu.

\section{ZAKLJUČAK}

Sjećanje na Vukovarsku bitku u razdoblju dužem od dvadeset godina bilo je praćeno i oblikovano nizom važnih kulturnih sadržaja, izložbi, tekstova i obilježavanja. Ono je povremeno zauzimalo ključno mjesto u raspravama koje se tiču nacionalnog identiteta, stvaranja države, oblikovanja poretka u gradu te načina na koji se treba odnositi spram prošlosti.

No, kako se pokazalo, nisu u isto vrijeme bila jednako važna sva pitanja, pa je tako društvena aktualizacija kulture sjećanja od 1991. do početka 1998. bila vođena težnjom da se u svoje domove vrati prognano stanovništvo te da se pamti i obnovi grad kakav je bio prije rata. Do kraja mirne reintegracije u radovima kulture sjećanja dominira narativizacija sjećanja te se, osobito u djelima dokumentarističkoga karaktera, aktualiziraju važnost sjećanja na grad prije razaranja i potreba za obnovom njegova povijesnog identiteta.

Nakon povratka prognanog stanovništva u grad u prvi plan dolazi borba protiv relativizacije istine, nastojanje da se jasno razgraniče agresor i žrtva. Aktualizacija kulture sjećanja odvija se u različitim smjerovima, obuhvaćajući etničke zajednice u samom gradu, širi nacionalni okvir te međunarodne odnose i međunarodne institucije. Posebno mjesto zadobivaju materijalna obnova grada te presude Međunarodnoga kaznenoga suda za zločine počinjene na području bivše Jugoslavije.

Naposljetku, proizlazeći iz prethodnih rasprava, javlja se tema važnosti sjećanja na povijesni događaj kakav je Vukovarska bitka za nacionalni identitet, koja je dominirala hrvatskom javnošću od početka 2013. Ključno je pitanje pritom je li događaj iz 1991. poseban događaj u hrvatskoj povijesti i zaslužuje li stoga Vukovar biti »mjesto posebnog pijeteta « ili u vođenju suvremene politike prioritet trebaju imati druga načela. U kontekstu vuko- 
varske kulture sjećanja najveća pozornost posvećuje se obilježavanju Dana sjećanja na žrtvu Vukovara.

U ovom radu krenulo se od postavke da se proces konstrukcije i recepcije kulturnih sadržaja isprepleće $s$ drugim važnim društvenim procesima koji na njega utječu. Smatramo da se pritom pokazalo da pristup koji naglašava dinamički model prenošenja sjećanja u modernosti predstavlja dobar okvir za analizu načina na koji je Vukovarska bitka kroz kulturu sjećanja bila vrednovana u hrvatskoj javnosti.

H. Welzer (2011: 374), analizirajući Holokaust u njemačkome obiteljskom pamćenju, pisao je: »Pola stoljeća, koje je već prošlo od holokausta, pokazalo je kroz kakve je promjene stanja odnosa i tumačenja taj događaj prelazio u kolektivnom sjećanju, čak i ako se promatra samo zapadno njemačko, a poslije i cjelokupno njemačko sjećanje«. Pokazalo se da u modernosti raste broj aktera koji se uključuju u proces aktualizacije sjećanja, od onih lokalnih preko nacionalnih do nadnacionalnih, kao i načini prenošenja sjećanja kroz nove medije, fotografiju, filmove, plakate ili internet. To dovodi do toga da se sjećanje susreće $\mathrm{s}$ ubrzanjem stvarnosti te se stoga od aktera očekuje da svoje sjećanje suočavaju s novim društvenim situacijama, da iznova odmjeravaju važnost prošlosti za sadašnjost i sadašnjosti za prošlost. Osim toga širi se i napetost između nastojanja da se stvari objektivno spoznaju i interpretativno zatvore i, s druge strane, težnje modernosti za novim - novim dokazima, novim perspektivama, originalnošću u tumačenju. Sve te teme pokazale su se relevantnima i pri pamćenju Vukovarske bitke. Tu su se otkrili raspon različitih perspektiva na prošlost i nastojanje da se jedan povijesni događaj relativno brzo resemantizira. Taj je slučaj tako na svoj način »prikazao« dinamiku sjećanja na djelu i uklopio se u jedno od najpoticajnijih područja studija sjećanja.

\section{LITERATURA}

Alexander, J. C. i Smith, P. (2005). Strogi program u kulturnoj teoriji. Elementi strukturalne hermeneutike (prijevod), Diskrepancija, 6 (10): 69-86.

Allcock, J., Biro, M., Dimitrijević, M., Gordy, E., Mertus, J. i Oloffson, R. (2010). Međunarodni tribunal za ratne zločine na području bivše Jugoslavije, u: C. Ingrao i T. A. Emmert (ur.). Suočavanje s jugoslavenskim kontraverzama: inicijativa naučnika. Sarajevo: Buybook, 335-372.

Assmann, A. (2008). Canon and Archive, u: A. Erll i A. Nunning (ur.). Cultural Memory Studies: An International and Interdisciplinary Handbook. Berlin - New York: Walter de Gruyter, 97-107. 
Berger, P. L. (1963). Invitation to Sociology: A Humanistic Perspective. New York: An Anchor Book.

Berger, P. L. i Kellner, H. (1991). Sociologija u novom ključu. Niš: Gradina.

Berger, P. L. i Luckman, T. (1992). Socijalna konstrukcija zbilje. Zagreb: Naprijed.

Bing, A. (2013). Vukovar i kultura sjećanja: mythos i epistheme recentne hrvatske povijesti, u: D. Živić i dr. (ur.). Vukovar' 91 - istina i/ili osporavanje: (između znanosti i manipulacije). Zagreb - Vukovar: Institut društvenih znanosti Ivo Pilar - Ogranak Matice hrvatske Vukovar, 137-156.

Čorkalo Biruški, D. i Ajduković, D. (2009). Od dekonstrukcije do rekonstrukcije traumatizirane zajednice: primjer Vukovara, Revija za socijalnu politiku, 16 (1): 1-24, doi: 10.3935/rsp.v16i1.774.

Eisenstadt, S. N. (2004). Mnogostruke modernosti, u: D. Roksandić (ur.). Uvod u komparationu historiju. Zagreb: Golden marketing - Tehnička knjiga, 219-244.

Erll, A. (2011). Memory in Culture. Basingstoke: Palgrave Macmillan, doi: $10.1057 / 9780230321670$.

Glavašević, S. (1992). Priče iz Vukovara. Zagreb: Matica hrvatska.

Hutton, P. H. (1993). History as an Art of Memory. Hanover: University Press of New England.

Jurčević, J. (2000). Povijesno značenje Vukovara ‘91., u: J. Jurčević (ur.). Vukovar '91: značenje, vrednote, identitet. Zagreb: Institut društvenih znanosti Ivo Pilar, 11-18.

Letica, S. (2004). Predgovor, u: T. Stockinger, Vukovar - grad koji je obranio Hrvatsku. Zagreb: Mato Lovrak, 7-8.

Karač, Z. (2004). Tragedija urbane baštine Vukovara. Razaranje hrvatskog i europskog identiteta grada 1991., u: J. Jurčević, D. Živić i B. Esih (ur.). Vukovar '91: međunarodni odjeci i značaj. Zagreb: Institut društvenih znanosti Ivo Pilar, 125-144.

Kardov, K. (2006). Reconstructing Community, Recreating Boundaries. Identity Politics and Production of Social Space in Post-War Vukovar. Trondheim: NTNU, Norwegian University of Science and Technology (Trondheim Studies on East European Cultures and Societies, 19).

Križić Roban, S. (2004). Pred zidom: strah od praznine. Teorijski prilog suvremenoj raspravi o problematici javne plastike, Radovi Instituta za povijesti umjetnosti, 28 (1): 366-377.

Kufrin, K. i Žanić, M. (2016). Obilježavanje i sjećanje. Značenje 18. 11. u godinama progonstva i vremenu nakon povratka, u: D. Živić i dr. (ur.). Što je Vukovar Hrvatskoj i Europi?. Zagreb - Vukovar: Institut društvenih znanosti Ivo Pilar - Ogranak Matice hrvatske u Vukovaru, 137-151.

Marijan, D. (2013). Obrana i pad Vukovara. Zagreb: Hrvatski institut za povijest.

Misztal, B. A. (2003). Theories of Social Remembering. Maidenhead, Philadelphia: Open University Press.

Nadilo, B. (2001). Donacijska obnova zgrada javne namjene u Vukovaru, Građevinar, 53 (10): 661-667.

Njavro, J. (1992). Glava dolje ruke na leđa. Zagreb: Quo Vadis.

Olick, J. K., Vinitzky-Seroussi, V.i Levy, D. (2011). Introduction, u: J. K. Olick, V. VinitzkySeroussi i D. Levy (ur.). Collective Memory Reader. Oxford: Oxford University Press, $3-62$. 
Oraić Tolić, D. (2009). Vukovarsko ratno pismo, u: Slavonija, Baranja i Srijem: vrela europske civilizacije. Zagreb: Galerija Klovićevi dvori, 581-585.

Pavlaković, V. (2013). Bolje grob nego rob: Hrvatska i Međunarodni kazneni sud za bivšu Jugoslaviju, u: R. Lukić, S. P. Ramet i K. Clewing (ur.). Hrvatska od osamostaljenja: rat, politika, društvo, vanjski odnosi. Zagreb: Golden marketing - Tehnička knjiga, 433-462.

Pavličić, P. (1992). Dunav. Zagreb: Znanje.

Pavličić, P. (1995). Šapudl. Zagreb: Znanje.

Pavličić, P. (1997). Vodič po Vukovaru. Zagreb: Mozaik knjiga.

Reed, I. i Alexander, J. C. (2008). Cultural Sociology, u: B. S. Turener (ur.). The New Blackwell Companion to Social Theory. Chichester: Willey-Blackwell, 378-408.

Rogić, I. (1993). Vukovar '91. i hrvatski nacionalni identitet, Društvena istraživanja, 2 (2-3): 501-519.

Rogić Nehajev, I. (1998). Smaragdni brid: Vukovar '91. i hrvatski identitet. Zagreb: Hrvatska sveučilišna naklada.

Ružić, S. i Živić, D. (2013). Ratni mortalitet Srba (bivše) općine Vukovar tijekom 1991., Scrinia Slavonica, 13 (1): 261-276.

Sjekavica, M. (2012). Sustavno uništavanje baštine - prema pojmu kulturocida/heritocida, Informatica museologica, 43 (1-4): 57-74.

Skoko, B. i Bagić, D. (2007). Image Vukovara u hrvatskoj javnosti - 15 godina nakon stradanja, u: D. Živić i I. Žebec (ur.). Vukovar - hrvatska baština i perspektive razvoja. Zagreb - Vukovar: Institut društvenih znanosti Ivo Pilar, 167-181.

Smith, A. D. (1998). Nacionalni identitet. Beograd: XX vek.

Smith, A. D. (1999). Myths and Memories of the Nation. Oxford: Oxford University Press.

Stanić, S. i Kutleša, A. (2008). Rat i okoliš, Polemos, 11 (1): 11-31.

Šimunović, Z. (1995). Vukovarski dnevnik. Zagreb: Školska knjiga.

Špoljar Vržina, S. (2007). Prilog antropologijskih promišljanja - identiteti Vukovara iz očišta domaćih i svjetskih eksperata savjeti i morala, u: D. Živić i I. Žebec (ur.). Vukovar - hrvatska baština i perspektive razvoja. Zagreb - Vukovar: Institut društvenih znanosti Ivo Pilar, 125-146.

Welzer, H. (2011). Holokaust u nemačkom porodičnom sećanju, u: F. Knige i N. Frei (ur.). Podsećanje na zločine. Novi Sad - Beograd: Platoneum - Savez jevrejskih opština Srbije, 346-361.

Yates, F. (2011). Umijeće pamćenja. Zagreb: Jesenski i Turk.

Zerubavel, E. (2007). Društvena sjećanja (prijevod), Diskrepancija, 8 (12): 167-197.

Žanić, M. (2008). Konstrukcija poslijeratnog prostora: simbolička izgradnja Vukovara, Polemos, 11 (2): 29-50.

Žanić, M. (2014a). Društveni okviri obilježavanja. Vukovarska bitka i dan sjećanja na žrtvu Vukovara 1991. godine, u: Kultura, identitet, društvo - europski realiteti. Osijek - Zagreb: Odjel za kulturologiju Sveučilišta - Institut društvenih znanosti Ivo Pilar, 262-277.

Žanić, M. (2014b). Društvena dinamika i simbolizacija prostora. Istraživanje oblikovanja mentalnih mapa stanovnika Vukovara, Socijalna ekologija, 23 (1): 39-56.

Živić, D. (2008). Posljedice srbijanske agresije kao odrednica poslijeratne obnove i razvitka Vukovara, Društvena istraživanja, 17 (1-2): 27-50. 
Živić, D. (2012). Izazovi i mogućnosti poslijeratne revitalizacije Grada Vukovara, Hrvatski geografski glasnik, 74 (1): 75-90.

Živić, D. (2013). Je li Vukovar (bio) srpski grad?, u: D. Živić i dr. (ur.). Vukovar '91. - istina i/ili osporavanje (između znanosti i manipulacije). Zagreb - Vukovar: Institut društvenih znanosti Ivo Pilar - Ogranak Matice hrvatske Vukovar, 103-119.

Živić, D. (2016). Ratne slike Vukovara - dokumenti zločina i čuvari sjećanja, u: D. Živić i dr. (ur.). Što je Vukovar Hrvatskoj i Europi?. Zagreb - Vukovar: Institut društvenih znanosti Ivo Pilar - Ogranak Matice hrvatske u Vukovaru, 201-215.

\section{IZVORI}

Bradarić, B. (2013). Ovčara na ćirilici, Večernji list, 11. siječnja 2013., str. 12.

Butigan, S. (2007). Slogan: u Vukovar za istinu i pravdu, Jutarnji list, 7. studenoga 2007., str. 43.

Butković, D. (2013). Postaje li Hrvatska izrazito konzervativno društvo?, Jutarnji list, 6. studenoga 2013., str. 9.

D. De. (1992). Kistom za Vukovar, Večernji list, 20. studenoga 1992., str. 15.

Dugandžija, M. (2008). Siniša Glavašević je i moj heroj, Globus, br. 939, 5. prosinca 2008.

Evidencija nestalih osoba, Uprava za zatočene i nestale, Ministarstvo branitelja, Zagreb, prosinac 2015.

Lukić, S. (1994). Vukovar to nije izgubljena bitka, Slobodna Dalmacija, 18. studenoga 1994.

Ljubičić, S. (2013). Vlada mora priznati poraz u Vukovaru, Slobodna Dalmacija, 17. studenoga 2013., str. 6.

Marković, M. (1993). S dvjesto ljudi obranio bi Vukovar, Slobodna Dalmacija, 17. studenoga 1993., str. 9.

Pavičić, J. (2010). Na Balkanu se povijest uči doma, Jutarnji list, 22. svibnja 2010., str. 65.

Pavičić, J. (2013). Devedesete se (opet) događaju, Slobodna Dalmacija, 20. studenoga 2013., str. 14-15.

Rašović, R. (2013). Igor Gilja: tata bi bio ponosan na mene, Večernji list, 13. listopada 2013., str. 22-23.

Nazor, A. (2014). Kako se promijenila retorika, u: »Vukovar 1991.-2014.« (prilog uz novine), Slobodna Dalmacija, 18. studenoga 2014., str. 2-5.

Reakcije na zbivanja u Vukovaru, Večernji list, 4. rujna 2013., str. 4.

Statut Javne ustanove »Memorijalni centar Domovinskog rata Vukovar« (2014).

Vukovarske novine, od broja 1 (svibanj 1992.) do broja 593 (rujan 2015.). 


\title{
Culture and Remembrance of War: the Battle of Vukovar and Its Social Repercussions
}

\author{
Mateo Žanić, Krešimir Kufrin, Dražen Živić
}

\begin{abstract}
SUMMARY
Considering the dynamic character of memory in modern times, this paper analyzes the ways of forming the culture of memory of the Battle of Vukovar in Croatia and the key discussions about it. It is assumed that remembrance is still important for the members of society, but its meaning and values are changing in response to the change in social relations. The content of remembrance has multiple layers that intertwine, but in critical periods, there is still a desire to code the significant events in the same manner. With that understanding of remembrance as a starting point in modern society, a question is posed about the existence of change in the remembrance culture of the Battle of Vukovar in the last 25 years and the way those changes can be interpreted. Cultural sociology developed an interpretative approach which can be used to investigate this research topic.
\end{abstract}

Interpreting the changes in the production and reception of cultural remembrance is based on available scientific papers, media articles, interpretation of key parts of cultural remembrance (books, movies, memorial services), and on the results of an interview-based empirical research. It is found that there are three stages in which the culture of memory was actualized in different ways.

In the first stage, which encompasses the period of exile (from 1991 to 1998), it was important to remember the Battle and the city before the war, so it could be restored when the citizens return. Various exhibitions and memorial services were organized, many statues built in this period. It is interesting to note that some of the Croatian most famous painters painted the motifs of Vukovar, thus encouraging the symbolic reconstruction of the city as well as keeping the memory alive. The Wall of Pain was built in in Zagreb in 1993 and some consider it the most authentic monument of the Croatian War of Independence, next to which the banished citizens of Vukovar often organized different commemorations. Nevertheless, the highest number of remembrance culture contents in this period belongs to the narration of remembrance, i.e. autobiographical and fictional writing about Vukovar and the Battle. Many survivors released books about their experience, writers wrote essays and poems about Vukovar, and the works of P. Pavličić and S. Glavašević evoked the strongest response in the public. Even though there are ongoing debates about whether the city could have been defended, whether it could have been returned under the sovereignty of the Republic of Croatia earlier, and whether the displaced population could have gotten more help, Vukovar is perceived as a key place of resistance to aggression against Croatia. Such representation of the city emphasized the need for the banished citizens to return to the city and to return the European spirit existing before the war to Vukovar.

In the second stage, lasting from 1998 to 2013, the idea that memory is a base for the fight against relativization of truth predominates. The key is to find out how cultural remembrance can transmit the truth about the battle and how it should be reflected on the social order in the city. That question was kept in mind during the renewal 
of the city and the building of new places of remembrance. The need to differ the aggressor and the victim was insisted upon, while Serbian representatives and Croatian politicians tried to relativize the relation between the aggressor and the victim. The first movie that dealt explicitly with the subject demonstrated how sensitive it was to show the Battle of Vukovar, its heroes and victims. The movie "Remember Vukovar" was first aired on Croatian television in November 2008 and it provoked a number of negative reactions from defense soldiers, which even contemplated suing the director. During that time, special attention was directed towards the International Criminal Court for war crimes in ex-Yugoslavia. Some of the verdicts were not well received in the society of remembrance, especially the verdicts for the "Vukovar Three"(V. Šljivančanin, M. Mrkšić and M. Radić). However, when Generals A. Gotovina and M. Markač were acquitted of war crimes on 16 November 2012, many concluded that Croatia won the legal war as well, and that the truth about the aggressors and victims was finally confirmed.

In the third stage, after 2013, the main aspect of the remembrance culture is the discussion of the importance of the Battle of Vukovar for national identity and inside politics. The results of the 2011 Census showed that there were $34.9 \%$ of Serbs in Vukovar. The representatives of the Independent Democratic Serb Party demanded to be allowed to use Serbian language and the Cyrillic alphabet on the basis of that data. That caused debates in Croatian public, because it meant that the city that had been occupied until 1998, would again have street names in Cyrillic. That led to disagreements about the implementation of The Constitutional Act on The Rights of National Minorities in the Republic of Croatia in Vukovar. The attention was mostly focused on the valuation of heroic deeds and victim suffering in the Croatian War of Independence in comparison to other national goals. The division was especially noticeable during the memorial service for the Vukovar Remembrance Day in 2013. Vukovar then became an important part of the national identity and politics, where one side believed that the biggest problem was the lack of respect towards the victims, while the other side was more concerned about the fact that the civil rights of minorities were not respected. This period is predominated by the tension surrounding the rutinization of memory. Rutinization is a process predominated by debates about whether one historical event should be reconstructed using facts and given over to institutions, or it should get wider symbolic value, important for formation or preservation of the group's opinion about itself. Some of the participants consider de-mitologization and de-emotionalization of historic events important, while others think that historic events develop the distinctive character of a group, and it is not possible to be emotionally detached when taking the standpoint of the victim.

It is concluded that the shifts in the interpretation of the importance of memory of the Battle of Vukovar suggest that there are different aspects in which the importance of the culture of memory is reflected in contemporary society. Acceleration of time, the greater number of ways to spread information about the past and the number of participants interpreting it influence the change of understanding of the past, in the way that its quick reinterpretation and revaluation becomes more possible, without making it less important.

KEY WORDS: the Croatian War of Independence, the Battle of Vukovar, cultural remembrance, national identity, commemoration 